\title{
SCIENTIFIC BASIS
}

OF INNOVATION ACTIVITY

https://doi.org/10.15407/scine17.06.083

YELATONTSEV, D. 0. 1, 2 (https://orcid.org/0000-0003-1043-418X), MUKHACHEV, A. P. ${ }^{2}$ (https://orcid.org/0000-0002-6025-3988),

and IVANYUK, O.V. ${ }^{3}$ (https://orcid.org/0000-0003-4112-837X)

'Dniprovsk State Technical University,

2, Dneprostroevskaya St., Kamianske, 51918, Dnipropetrovsk Region, Ukraine,

+380 56956 0667, science@dstu.dp.ua

${ }^{2}$ Poljakov Institute of Geotechnical Mechanics, NAS of Ukraine,

2, Simferopolskaya St., Dnipro, 49005, Ukraine,

+380 56746 0151, igtmnanu@ukr.net

${ }^{3}$ Igor Sikorsky Kyiv Polytechnic Institute National Technical University of Ukraine,

37, Peremohy Ave., Kyiv, 03056, Ukraine,

+380 44204 8573, sec@xtf.kpi.ua

\section{AN EFFECTIVE BIOSORBENT DERIVED FROM PRODUCTION WASTE FOR WATER TREATMENT: STUDYING THE ADSORPTION OF SYNTHETIC DYES}

Introduction. Eco-friendly disposal of food waste, in particular, nutshells and fruit kernels, is an important issue to ensure sustainable nature management. These secondary raw materials are the source of valuable polymeric materials, cellulose and lignin.

Problem Statement. IGiven the capacity of the food industry in Ukraine and the amount of waste produced, the development of technologies for processing lignin-cellulose biomass is an important research and practical issue.

Purpose. The purpose of this research is to study the adsorption properties of chemically modified biosorbent based on plant materials concerning synthetic dyes of different types and classes; to assess the feasibility of biosorbent production and efficiency of its application in water treatment.

Materials and Methods. Lignocellulose sorbent (LCS) has been synthesized from non-wood raw materials by chemical modification with the use of phosphoric acid with the addition of urea in an aqueous media. The Fourier transform infrared and standard methods of plant raw material analysis have been used to determine the physicochemical characteristics of LCS. The adsorption of anionic (methyl orange, alizarin red S, eosin Y), cationic (methylene blue, neutral red), and nonionic (aniline yellow) dyes on LCS from aqueous solution has been studied in the batch mode.

Results. The adsorption capacity of LCS towards cationic dyes $(47.0-53.3 \mathrm{mg} / \mathrm{g})$ is higher than that of anionic $(22.2-36.9 \mathrm{mg} / \mathrm{g})$ and nonionic $(4.7 \mathrm{mg} / \mathrm{g})$ ones. The adsorption kinetics have been adequately described by a pseudo-second-order equation. Adsorption of all classes of dyes on LCS is thermodynamically feasible, spontaneous, and endothermic process. The liquid by-product of LCS production contains $15 \%$ nitrogen and 10\% phosphorus, so it may be used as a fertilizer.

Citation: Yelatontsev D. O., Mukhachev A. P., and Ivanyuk O. V. An Effective Biosorbent Derived from Production Waste for Water Treatment: Studying the Adsorption of Synthetic Dyes. Sci. innov. 2021. V. 17, no. 6. P. 83-96. https://doi.org/10.15407/scine17.06.083 
Conclusions. The proposed method for processing food waste provides obtaining effective sorbent and liquid NP-fertilizer. LCS removes both cationic and anionic pollutants from water, so it may be considered a promising biosorbent for water purification.

Keywords: cellulose, synthetic dyes, adsorption, kinetics, thermodynamics, walnut shell, apricot stone, and waste recycling.

According to the principles of "sustainable production" and "green chemistry", walnut shell (WS) and apricot kernel stones (AS), as widespread agricultural waste, are considered promising sources of qualitative lignocellulosic feedstock [1; 2]. Searching for methods of chemical modification of this feedstock to obtain materials with improved sorption characteristics, as an alternative to industrial sorbents, is of particular research interest. In the future, these materials could become an alternative to industrial sorbents, such as zeolites and activated carbon, which are quite expensive [3]. The most promising areas of application of this non-wood lignocellulosic waste are metal ions and dyestuff removal from aqueous solutions; production of pharmaceuticals and biologically active food additives [4; 5].

Due to availability and low cost [6], the use of renewable lignocellulosic materials as sorbents is of growing interest. Nevertheless, these wastes don't have the required exchange capacity, removal selectivity, and characterized by relatively low sorption capacity [7]. Therefore, before they are utilized as sorbents, preliminary modification is required. That involves the latest achievements in biotechnology, nanotechnology, etc. [8].

One of the most rational methods in the development of effective lignocellulosic sorbents (LCS) is a chemical modification of natural cellulosecontaining materials [9]. Such treatment leads to immobilization of active centers, increasing sorption capacity, selectivity and reduces process longitude. In this direction, some interesting techniques have already been proposed [7; 9-11]. There are some extensive reviews [12;13] available on this topic.

By now, a great number of studies focused on such lignocellulosic waste as an almond shell [14], corn silk [15], tea waste, orange peel [16], corn stalks [17], corn cob, and sunflower seed shell [18] modified by various chemical reagents, as well as raw feedstock, proved that these materials are capable of removing various classes of dyes from water.

A well-known method for studying adsorption properties of lignocellulosic materials is the adsorption from aqueous solutions, wherein the synthetic dyes are used as adsorbate [19; 20]. To assess the feasibility of using LCS for water treating, adsorption of methylene blue onto WS [1;21;22] and AS [23] have already been studied. By now, several extensive reviews concerning the use of low-cost adsorbents based on the agricultural waste for dye removal from water have been published [24-26]. The reviews have indicated that the use of the untreated plant waste usually does not ensure the desired effect in removing dyes. Modification of WS by organic surfactants (epichlorohydrin, diethylenetriamine, aspartic acid) dramatically increases adsorption capacity towards dyes, but such treatment is rather expensive and produces a harmful effluent [9; 27].

Present work focused on the development of new types of LCS from non-wood feedstock (WS and AS) via eco-friendly chemical modification. Initial assessment of LCS physicochemical properties was carried through the adsorption of dyes from model aqueous solution. The following types of synthetic dyes were studied: anionic (Methyl orange, Alizarin red S, Eosin Y), cationic (Methylene blue, Neutral red), and non-ionic (Aniline yellow). The influence of contact time and equilibrium dye concentration on LCS adsorption capacity was studied. The mechanism of dyestuff adsorption was established from isotherm, kinetic and thermodynamic studies. The main purpose of this research was to provide an inexpensive and effective green sorbent for water treatment.

Materials and reagents. Pristine WS (Juglans Regia L.) and AS (Prunus Armeniaca L.) were supplied by the Odeskiy Oliynoekstraktsiyniy Zavod 
(Odesa, Ukraine). The mix of the raw feedstock was preliminary air-dried, then crushed and sized. The particles between 0.8 and $1.6 \mathrm{~mm}$ were chosen for further studies.

Commercial dyes Methyl orange (MO), Alizarin red S (AR), Eosin Y (EY), Methylene blue (MB), Neutral red (NR), and Aniline yellow (AY) were of analytical grade. The chemical properties of the dyes are given in Table 1 [28].

The model solutions of dyes were prepared by the solvation of the appropriate weight of dry reagent in distilled water. Phosphoric acid, hydrochloric acid, sodium hydroxide, and carbamide (urea) were of analytical grade.
Preparation of modified sorbent. To obtain a modified lignocellulosic sorbent (LCS) a certain weight of the raw material $(100 \mathrm{~g})$ was treated with $250 \mathrm{ml}$ of a $25 \% \mathrm{NH}_{4} \mathrm{OH}$ solution at a temperature of $25{ }^{\circ} \mathrm{C}$ for 4 hours. After that, the sample was separated from the ammonia and washed in distilled water to achieve a pH of 7.0-7.5. Then the sample was treated by activating solution, which consisted of $20 \% \mathrm{H}_{3} \mathrm{PO}_{4}, 40 \% \mathrm{CO}\left(\mathrm{NH}_{2}\right)_{2}$, and $40 \% \mathrm{H}_{2} \mathrm{O}$. The volume of activating solution added was $300 \mathrm{ml}$ at a temperature of $25^{\circ} \mathrm{C}$. Activation lasted 1 hour under vigorous agitation by a magnetic stirrer. Then the solid phase was separated and heated in an electric oven for 3 hours at

Table 1. General Properties and Chemical Structure of Studied Dyes

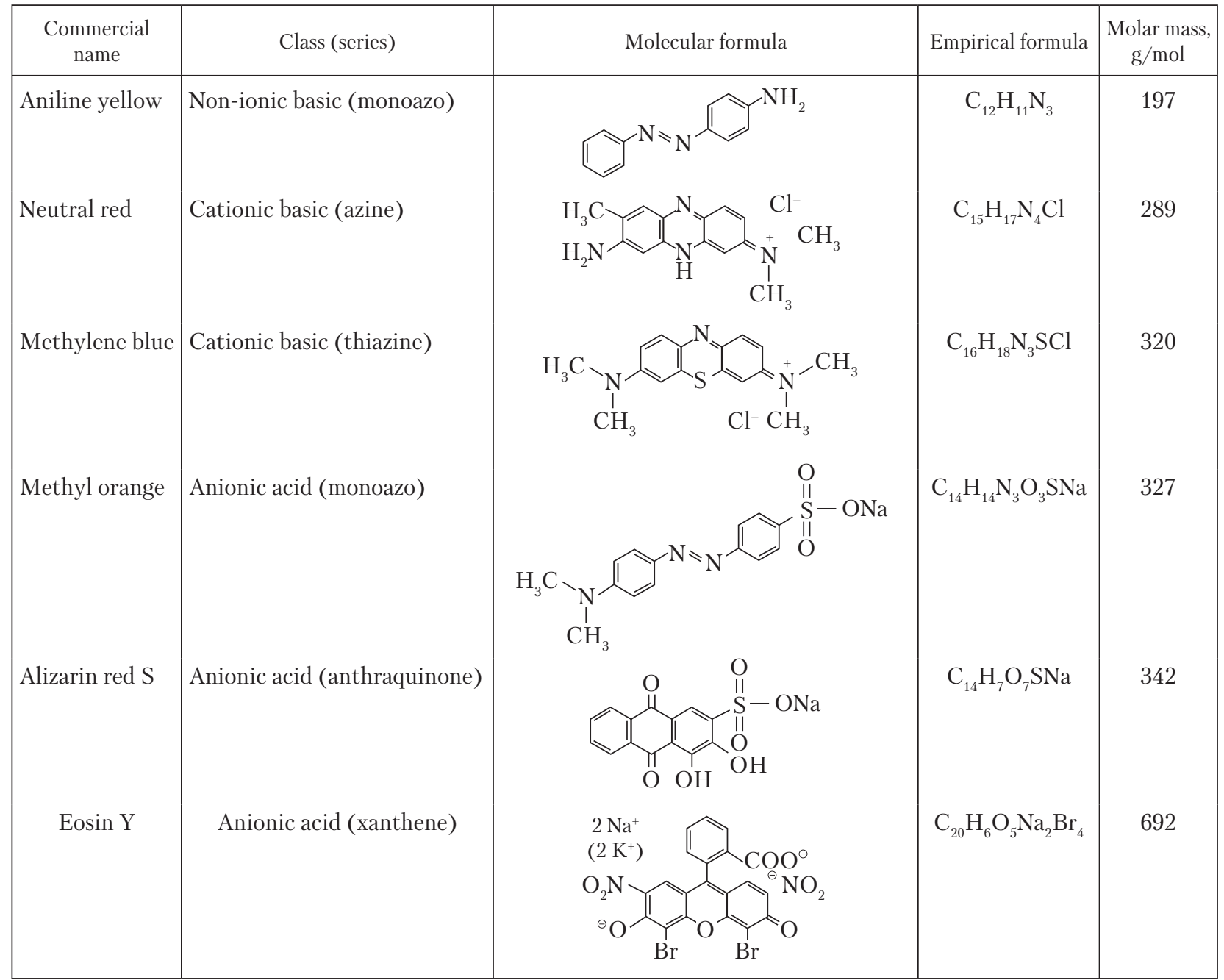


a temperature of $130{ }^{\circ} \mathrm{C}$. Afterward, the hot sample was placed in distilled water with a temperature of $20-30{ }^{\circ} \mathrm{C}$ and was kept in it for 1 hour. Then it was washed off with deionized water and conditioned in distilled water for 6 days. After that, LCS was dried at $60^{\circ} \mathrm{C}$ and stored in a desiccator.

Analytic methods. The main chemical components of feedstock and modified sorbent (lignin, hemicellulose, organic extractives, ash, and moisture) were analyzed according to the Technical Association of Pulp and Paper Industry standards that have been previously described [29;30].

The concentration of dyes was measured with the use of a spectrophotometer UV-1100 at the following wavelengths, nm: EY-517; AR-423; MO-460; AY-386; MB-665; NR-529. The surface functional groups and structure of raw material and LCS were studied with the use of a Fourier Transform Infrared Spectroscopy (FTIR). FTIR spectra were recorded on a Magna 560, Nicolet, Thermo Electron Corp., in the range of $400-4000 \mathrm{~cm}^{-1}$ with a resolution of $4 \mathrm{~cm}^{-1}$. The dried samples were grounded and blended with $\mathrm{KBr}$ before being pressed into pellets.

Adsorption experiments. Batch adsorption experiments were conducted in a set of conical flasks containing $1.0 \mathrm{~g}$ of LCS and $100 \mathrm{ml}$ of dye solution of appropriate concentration (50, 100, $250,500,750$, and $1500 \mathrm{mg} / \mathrm{l}$ ) at a $\mathrm{pH}=7$. The $\mathrm{pH}$ was adjusted with the use of $0.1 \mathrm{M} \mathrm{HCl}$ or $0.1 \mathrm{M}$ $\mathrm{NaOH}$. The flasks were agitated at $150 \mathrm{rpm}$ with the use of a temperature-controlled water bath with a shaker and maintained at constant for $24 \mathrm{~h}$ until the equilibrium was reached. Afterward, the dyestuff concentration in the supernatant solution was determined spectrophotometrically.

The amount of adsorbed dye at equilibrium, $q$, $\mathrm{mg} / \mathrm{g}$, and at time $t, q_{\mathrm{t}}, \mathrm{mg} / \mathrm{g}$, were calculated by equations (1)-(2) [31]:

$$
\begin{aligned}
& q_{\mathrm{e}}=\frac{C_{0}-C_{\mathrm{e}}}{m} \cdot \mathrm{V}, \\
& q_{\mathrm{e}}=\frac{C_{0}-C_{\mathrm{t}}}{m} \cdot \mathrm{V},
\end{aligned}
$$

where $C_{0}, C_{\mathrm{e}}, C_{\mathrm{t}}$ is the initial, equilibrium, and dye concentration at a certain time, respectively, $\mathrm{mg} / \mathrm{l}, m$ is the dry adsorbent mass, $\mathrm{g}$, and $V$ is the volume of the dye solution, 1 .

All adsorption tests were performed with three replicates and the mean values were used for subsequent analysis.

Adsorption isotherms. Langmuir, Freundlich, Temkin, and Dubinin-Radushkevich (D-R) isotherm models were used to examine the relationship between the amount of adsorbed dye and its equilibrium concentration. The linear forms of the abovementioned isotherms are given by Eqs. (3)-(6) [32]:

$$
\begin{gathered}
\frac{C_{\mathrm{e}}}{q_{\mathrm{e}}}=\frac{1}{q_{\mathrm{e}} K_{\mathrm{L}}}+\frac{C_{\mathrm{e}}}{q_{\mathrm{m}}}, \\
\log q_{\mathrm{e}}=\log K_{\mathrm{F}}+\frac{1}{n} \log C_{\mathrm{e}}, \\
q_{\mathrm{e}}=\frac{R T}{b_{T}} \ln A_{\mathrm{T}}+\frac{R T}{b_{T}} \ln C_{\mathrm{e}}, \\
q_{\mathrm{e}}=q_{\mathrm{s}} \exp \left(-\mathrm{B} \varepsilon^{2}\right),
\end{gathered}
$$

where $q_{\mathrm{e}}$ is the equilibrium dye concentration on the adsorbent $(\mathrm{mg} / \mathrm{g}), C_{\mathrm{e}}$ the equilibrium dye concentration in the solution $(\mathrm{mg} / \mathrm{l}), q_{\mathrm{m}}$ the monolayer adsorption capacity of the adsorbent (mg/g), $K_{\mathrm{L}}$ is the Langmuir adsorption constant $(\mathrm{l} / \mathrm{mg}), K_{\mathrm{F}}(\mathrm{mg} / \mathrm{g})$ and $n$ are Freundlich constants, $b_{\mathrm{T}}(\mathrm{J} / \mathrm{mol})$ and $A_{\mathrm{T}}(\mathrm{l} / \mathrm{g})$ are Temkin constants related to the heat of sorption and equilibrium binding constant, respectively, $q_{\mathrm{s}}$ is the $\mathrm{D}-\mathrm{R}$ monolayer capacity $(\mathrm{mg} / \mathrm{g}), B$ is a constant related to sorption energy, $\varepsilon$ is the Polanyi potential which is related to the equilibrium concentration as $\varepsilon=$ $=R T \ln \left[1+1 / C_{\mathrm{e}}\right], R$ is the universal gas constant, $T$ is the absolute temperature $(\mathrm{K})$. The constant $B\left(\mathrm{~mol}^{2} / \mathrm{J}^{2}\right)$ gives the mean free energy of sorption per molecule of the sorbate when it is transferred to the surface of the solid from infinity in the solution and was calculated from the relationship $E=1 /(2 B)^{0.5}$.

According to the Langmuir isotherm, a dimensionless equilibrium parameter $R_{\mathrm{L}}$ (separation factor) is defined by Eq. (7) [33]:

$$
R_{\mathrm{L}}=\frac{1}{1+K_{\mathrm{L}} C_{0}},
$$

where $K_{\mathrm{L}}$ is the Langmuir constant and $C_{0}$ is the initial dye concentration $(\mathrm{mg} / \mathrm{l})$. The value of $R_{\mathrm{L}}$ 
indicates the type of the isotherm to be either unfavourable $\left(R_{\mathrm{L}}>1\right)$, linear $\left(R_{\mathrm{L}}=1\right)$, favourable $\left(0<R_{\mathrm{L}}<1\right)$ or irreversible $\left(R_{\mathrm{L}}=0\right)[32 ; 33]$.

Adsorption kinetics. Kinetic experiments were conducted by contacting $1.0 \mathrm{~g}$ LCS with $100 \mathrm{ml}$ of dye solution $(1 \mathrm{mmol} / \mathrm{l})$ at $278,298,323 \mathrm{~K}$, and at $\mathrm{pH}=7$ for $6 \mathrm{~h}$ of continuous shaking. The concentration of dye in the supernatant was determined at different time intervals.

The kinetics of dyestuff adsorption onto LCS was studied with the use of five common models: pseudo-first-order, pseudo-second-order, intra-particle diffusion, film diffusion, and Elovich model, expressed by Eqs. (8)-(12) [34]:

$$
\begin{gathered}
\ln \left(q_{\mathrm{e}}-q_{\mathrm{t}}\right)=\ln q_{\mathrm{e}}-k_{1} t, \\
\frac{t}{q_{\mathrm{t}}}=\frac{1}{K_{2} q_{\mathrm{e}}^{2}}+\frac{t}{q_{\mathrm{e}}}, \\
q_{\mathrm{t}}=k_{3} t^{0.5}+\mathrm{C}^{*}, \\
B=-0.4977-\ln \left(1-q_{\mathrm{t}} / q_{\mathrm{e}}\right), \\
q_{\mathrm{t}}=\frac{1}{\beta} \ln (\alpha \beta)+\frac{1}{\beta} \ln t,
\end{gathered}
$$

where $q_{\mathrm{e}}$ is the amount of concentration of adsorbate at equilibrium, $\mathrm{mg} / \mathrm{g}, q_{\mathrm{t}}$ is the amount of dye solute adsorb per unit weight of LCS at time $t$, $\mathrm{mg} / \mathrm{g}, k_{1}$ is the rate constant, $1 / \mathrm{min}, k_{2}, \mathrm{~g} /(\mathrm{mg} \cdot \mathrm{min})$ is the second-order rate coefficient, $k_{3}$ is the intraparticle diffusion rate constant $\mathrm{mg} /\left(\mathrm{g} \cdot \mathrm{min}^{0.5}\right)$, $C^{*}, \mathrm{mg} / \mathrm{g}$ represents the thickness of the boundary layer, $q_{\mathrm{t}} / q_{\mathrm{e}}$ represents the fraction of adsorbate adsorbed at different time, $B$ is a mathematical function of $q_{\mathrm{t}} / q_{\mathrm{e}}, \alpha$ and $\beta$ are the Elovich coefficients, where $\alpha$ represents the initial adsorption rate $\mathrm{mg} /(\mathrm{g} \cdot \mathrm{min})$ and $\beta$ is related to the extent of surface coverage and activation energy for chemisorption, g/mg.

Thermodynamics studies. Thermodynamic parameters (Gibbs free energy $\Delta G^{0}$, enthalpy $\Delta H^{0}$, and entropy $\Delta S^{0}$ ) of dyestuff adsorption onto LCS at different temperatures (278, 298, and $323 \mathrm{~K}$ ) were calculated from the equations (13)-(15) [35]:

$$
\begin{gathered}
\Delta \mathrm{G}^{0}=-R T \ln \frac{q_{\mathrm{e}}}{C_{\mathrm{c}},} \\
\ln \frac{q_{\mathrm{e}}}{C_{\mathrm{c}}}=-\frac{\Delta \mathrm{H}^{0}}{R T}+\frac{\Delta \mathrm{S}^{0}}{R}, \\
\Delta \mathrm{G}^{0}=\Delta \mathrm{H}^{0}-T \Delta S^{0} .
\end{gathered}
$$

In this study, the values of the Langmuir constant $K_{\mathrm{L}}$ (expressed in $1 / \mathrm{mol}$ ) were used as equilibrium constants to calculate thermodynamic parameters of dye sorption by LCS.

The isosteric heat of sorption $\left(\Delta H_{x}\right)$ is defined as the energy difference between the state of the system before and after the sorption of a differential amount of sorbate on the sorbent surface. Values of $\Delta H_{\mathrm{x}}$ below $80 \mathrm{~kJ} / \mathrm{mol}$ indicate physical sorption, and values of $\Delta H_{\mathrm{x}}$ between 80 and $400 \mathrm{~kJ} / \mathrm{mol}$ suggest chemical sorption [18]. The isosteric heat of sorption was estimated with the use of the equation:

$$
\frac{d\left(\ln C_{\mathrm{e}}\right)}{d(1 / T)}=-\frac{\Delta H_{\mathrm{x}}}{R},
$$

where $C_{\mathrm{e}}$ is the equilibrium concentration of sorbate in solution $(\mathrm{mg} / \mathrm{l})$ at constant surface loading, $R$ is the universal gas constant and $T$ is the temperature $(\mathrm{K})$. Values of $\Delta H_{\mathrm{x}}$ obtained from the slope of the plots of $\ln C_{\mathrm{e}}$ versus $1 / T$ for each dye (not shown).

Error analysis. To compare the adequacy and accuracy of the model's equations with experimental data, error analysis was carried out. Linear regression coefficient $R^{2}$ (the determination coefficient) and nonlinear error function - the Chisquare test, $\chi^{2}$ were used. The standard equations of these coefficients are as follows [32]:

$$
\begin{gathered}
R^{2}=\frac{\left(q_{\mathrm{e}, \mathrm{meas}}-\overline{q_{\mathrm{e}, \mathrm{calc}}}\right)^{2}}{\sum\left(q_{\mathrm{e}, \mathrm{meas}}-\overline{q_{\mathrm{e}, \mathrm{calc}}}\right)^{2}+\left(q_{\mathrm{e}, \text { meas }}-q_{\mathrm{e}, \mathrm{calc}}\right)^{2}}, \\
\chi^{2}=\sum_{i=1}^{n} \frac{\left(q_{\mathrm{e}, \mathrm{calc}}-q_{\mathrm{e}, \mathrm{meas}}\right)^{2}}{q_{\mathrm{e}, \mathrm{meas}}},
\end{gathered}
$$

$q_{\mathrm{e}, \text { meas }}$ is the measured adsorbate concentration at equilibrium (mg/g), $q_{\mathrm{e}, \text { calc }}$ is the calculated adsorbate concentration at equilibrium $(\mathrm{mg} / \mathrm{g}), N$ is the number of data points in the experiment. Smaller values of $\chi^{2}$ and higher values of $R^{2}$ indicate better model fitting and better correlation between the experimental and calculated data with the model equation [32].

Characterization of LCS. It was previously shown, that the typical composition of WS and AS is $\alpha$-cellulose (25-35\%), hemicellulose (25$30 \%$ ), and lignin $(30-40 \%)$, which percentages depend on the climate and growing conditions [12]. 


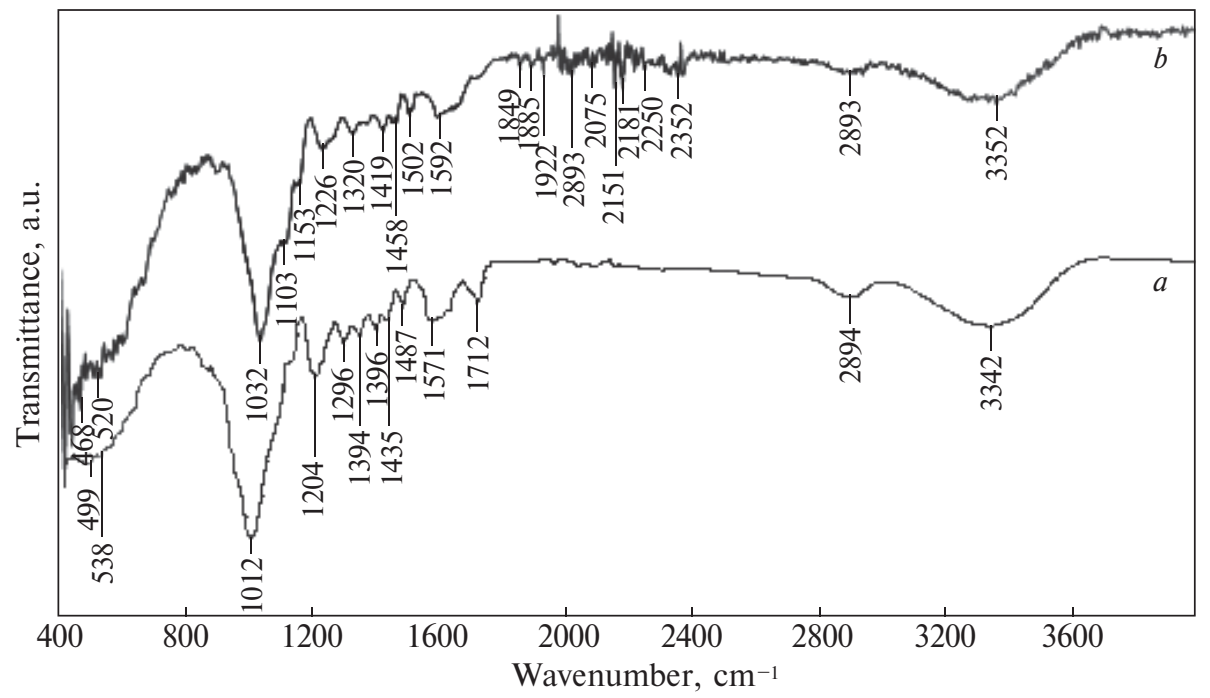

Fig. 1. FTIR spectra: $a-$ raw WS+AS; $b-$ LCS

Also, both materials contain minor components, such as extractives (about 1-3\%) and ash (up to $5 \%$ ) [36]. Studied feedstock contained below-average content of hemicellulose and lignin, which eased its conversion into sorbent (Table 2).

Due to the presence of lignin and cellulose in structure, LCS contains various surface groups that can interact with dye molecules. The presence of these surface groups in the structure of LCS was studied by FTIR spectroscopy (Fig. 1). The FTIR spectra of the raw WS+AS (Fig. 1, $a$ ) display bonds and peaks, assigned to functional groups of natural polysaccharide compounds (Table 3) [22].

Comparing the spectra of WS+AS and LCS it can be noticed that the intensity of peaks assig-

Table 2. Chemical Composition Raw

Feedstock (WS+AS) and Modified Sorbent (LCS)

\begin{tabular}{|l|r|r|}
\hline \multirow{2}{*}{\multicolumn{1}{|c|}{ Component }} & \multicolumn{2}{|c|}{ Content, \% } \\
\cline { 2 - 3 } & WS+AS & \multicolumn{1}{c|}{ LCS } \\
\hline a-cellulose & $35 \pm 1.0$ & $76 \pm 1.0$ \\
Lignin & $26.6 \pm 0.5$ & $4.0 \pm 0.5$ \\
Hemicelluloses & $20.5 \pm 0.5$ & $2.5 \pm 0.5$ \\
Ash & $4.9 \pm 0.5$ & $7.0 \pm 0.5$ \\
Extractives & $1.2 \pm 0.1$ & $0.4 \pm 0.1$ \\
Moisture & $11.8 \pm 0.5$ & $10.1 \pm 0.5$ \\
\hline
\end{tabular}

ned to some characteristic functional groups was either minimized (vibrations of aromatic rings in lignin) or lightly shifted (stretching of $-\mathrm{OH}$ and $-\mathrm{COOH}$ groups in cellulose) after modifi-

Table 3. Summary of the FTIR Spectra of WS+AS and LCS

\begin{tabular}{|c|c|c|}
\hline \multicolumn{2}{|c|}{ Adsorption band, $\mathrm{cm}^{-1}$} & \multirow{2}{*}{ Assignment } \\
\hline $\mathrm{WS}+\mathrm{AS}$ & LCS & \\
\hline $499 ; 538$ & $468 ; 520$ & $\begin{array}{l}\text { Skeletal deformation of aromatic } \\
\text { rings in lignin }\end{array}$ \\
\hline 1012 & 1032 & $\begin{array}{l}-\mathrm{OCH}_{3} \text { groups in lignin; } \mathrm{C}-\mathrm{O} \\
\text { stretching in polysaccharides }\end{array}$ \\
\hline- & 1103 & $\begin{array}{l}\mathrm{P}-\mathrm{O}-\mathrm{H} \text { vibrations in phospho- } \\
\text { rous ether groups }\end{array}$ \\
\hline- & 1153 & $\begin{array}{l}\mathrm{P}=\mathrm{O} \text { vibrations in phosphorous } \\
\text { ether groups }\end{array}$ \\
\hline 1204 & 1226 & $\begin{array}{l}\text {-OH bend in cellulosic alcohol } \\
\text { groups }\end{array}$ \\
\hline $1296-1487$ & $1320-1502$ & $\begin{array}{l}\mathrm{C}=\mathrm{C} \text { aromatic and }-\mathrm{OH} \text { pheno- } \\
\text { lic stretching in lignin }\end{array}$ \\
\hline 1571 & 1592 & $\mathrm{C}=\mathrm{O}$ stretching in $-\mathrm{COOH}$ groups \\
\hline 1712 & - & $\begin{array}{l}\mathrm{C}=\mathrm{O} \text { stretching in non-conjuga- } \\
\text { ted ketones groups }\end{array}$ \\
\hline- & 1849-2352 & $\begin{array}{l}\mathrm{O}-\mathrm{H} \cdots \mathrm{O} \text { vibrations in hydrogen } \\
\text { bonds of }\left(\mathrm{NH}_{4}\right) 2 \mathrm{CO} \cdot \mathrm{H}_{3} \mathrm{PO}_{4}\end{array}$ \\
\hline 2894 & 2893 & $\begin{array}{l}\mathrm{C}-\mathrm{H} \text { bonds in }-\mathrm{CH}_{3} \text { and }-\mathrm{CH} 2 \\
\text { groups of cellulose }\end{array}$ \\
\hline 3342 & 3352 & $\begin{array}{l}\text { Stretching of }-\mathrm{OH} \text { groups in po- } \\
\text { lysaccharides }\end{array}$ \\
\hline
\end{tabular}


cation. It is caused by a significant decrease in lignin content due to delignification by $\mathrm{NH}_{4} \mathrm{OH}$ and the degradation of hemicelluloses during acid treatment.

Fig. $1, b$ shows that in the spectrum of LCS, where the broadband in range of $1849-2352 \mathrm{~cm}^{-1}$ emerged, corresponding to the vibrations in hydrogen bonds of $\left(\mathrm{NH}_{4}\right)_{2} \mathrm{CO} \cdot \mathrm{H}_{3} \mathrm{PO}_{4}$ [37]. Incorporation of phosphorus-containing groups into the cellulose matrix also leads to the appearance of peaks at 1103 and $1153 \mathrm{~cm}^{-1}$, corresponding to vibrations of $\mathrm{P}-\mathrm{O}-\mathrm{H}$ and $\mathrm{P}=\mathrm{O}$ groups [10]. Thus, LCS was impregnated by phosphorus ether groups - OPO $(\mathrm{OH})_{2}$.

These observations indicate that in dyestuff adsorption mechanism may be involved the electrostatic interactions between the negatively charged surface groups of the LCS (as a result of dissociation of phosphorus ether groups) and the cationic dyes, as well as hydrogen bonding (lignocellulosic and phosphorus ether -OH...non-ionic dye).

According to the above-mentioned conclusions, as well as previously published data [38], the possible mechanism of phosphorylation of cellulose derived from WS+AS in the presence of urea in an aqueous medium may be presented as follows
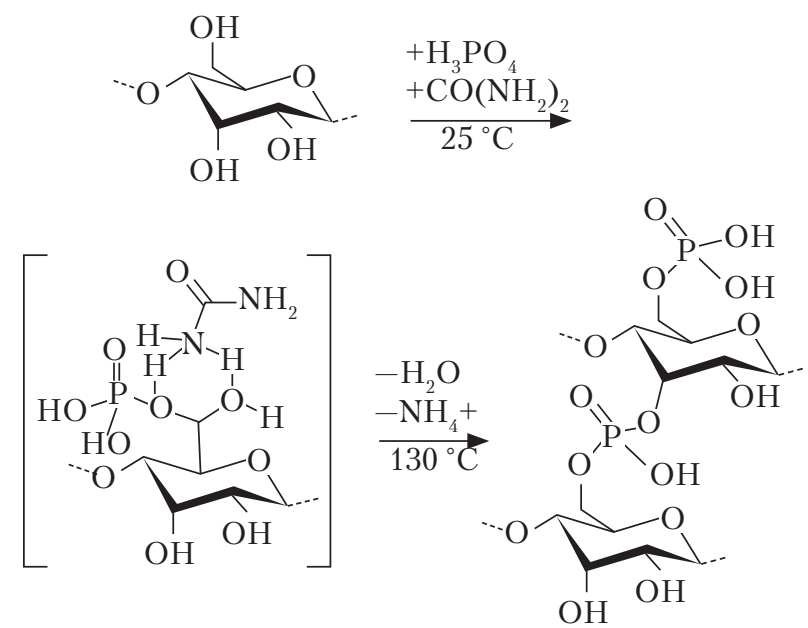

Under these conditions, the formation of compound $\left(\mathrm{NH}_{4}\right)_{2} \mathrm{CO} \cdot \mathrm{H}_{3} \mathrm{PO}_{4}$, which incorporates in the structure of cellulose, seems highly possible [39]. The only by-product of LCS production is aqueous ammonia with dissolved organic compo-

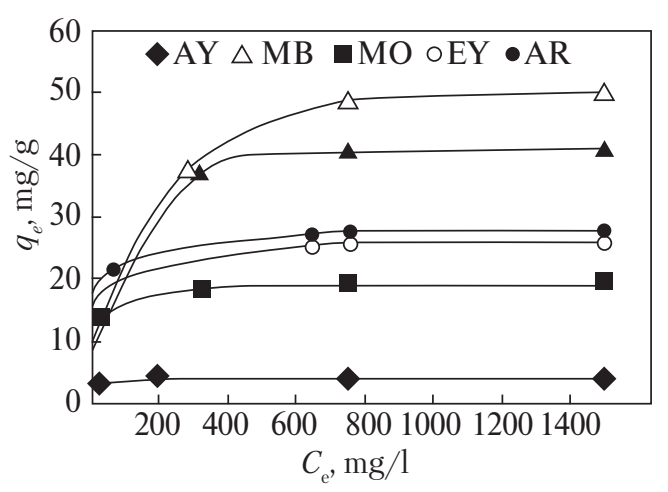

Fig. 2. Adsorption isotherms of dyes onto LCS. Operating conditions: $\mathrm{pH}=7.0$; LCS dosage $1 \mathrm{~g} / \mathrm{l}$; temperature $298 \mathrm{~K}$

nents of original feedstock (mainly lignin and hemicellulose). Whereas this solution contains roughly $15 \% \mathrm{~N}$ and $10 \% \mathrm{P}$, it should be considered a liquid fertilizer.

Adsorption isotherms. The sorption isotherms are presented in Fig. 2.

The isotherm constants of the dyestuff adsorption process onto LCS are listed in Table 4.

For all dyes the values of the $1 / n$ are lesser than one, while the values of $R_{\mathrm{L}}$ lie between 0 and 1 , suggesting favorable sorption [18]. Because of the values of the $R^{2}$ and $\chi^{2}$, experimental data of anionic dyes sorption onto LCS were more appropriate to the Freundlich isotherm model, whereas the Langmuir isotherm gives a better fit for the cationic dyes. Probably, it might have been explained by a different charge of dyes molecules. Adsorption of negative charged dyes molecules (MO, AR, EY) onto LCS takes place with the formation of multilayers and even filling of the pores, whereas electrostatic interactions between surface groups of LCS and positively-charged dyes molecules (NR, $\mathrm{MB}$ ) leads to monolayer sorption. The values of the $K_{\mathrm{L}}$ for NR and MB are higher than those for MO, AR, EY, and AY, suggesting a stronger binding between cationic dyes and the LCS surface. In the case of MO, AR, EY, and AY, the lower values of the binding constant could also be explained by decreasing diffusion of relatively large dye molecules into the pores of LCS.

According to the Temkin model [12], there is a linear decrease in the heat of adsorption of the 
molecules in the layer, due to the adsorbate-adsorbate interactions. The good fitting of the Temkin isotherm to experimental data $\left(R^{2}>0.97\right)$ indicates the strong interaction between the cationic dyes molecules and LCS. Temkin model predicts a uniform distribution of binding energies over the quantity of surface binding adsorption sites, wherein the range and distribution should depend strongly on the density and distribution of functional groups both on the dye and LCS surfaces [3]. The equilibrium binding constant increased from 1.848 to $8.349 \mathrm{l} / \mathrm{g}$ within the following sequence $\mathrm{AY}<\mathrm{EY}<\mathrm{AR}<\mathrm{MO}<\mathrm{NR}<\mathrm{MB}$. The Temkin model is an appropriate model for the sorption based on strong electrostatic interactions between opposite charges [14]. This suggests that the uptake heat of the adsorbate dye molecules in the absorbed layer decreases as positive charge per molecule within the above-indicated row goes down.

Table 4. Adsorption Isotherm Constants

for the Adsorption of Dyes onto LCS

\begin{tabular}{|c|c|c|c|c|c|c|}
\hline \multirow{2}{*}{ Parameter } & \multicolumn{6}{|c|}{ Dye } \\
\hline & EY & AR & MO & AY & MB & NR \\
\hline$q_{\mathrm{e}}, \mathrm{mg} / \mathrm{g}$ & 29.55 & 35.53 & 20.23 & 3.452 & 43.56 & 51.73 \\
\hline$K_{\mathrm{L}}, \mathrm{l} / \mathrm{mg}$ & 0.021 & 0.013 & 0.036 & 0.053 & 0.113 & 0.113 \\
\hline$R_{\mathrm{L}}$ & 0.986 & 0.995 & 0.988 & 0.952 & 0.996 & 0.991 \\
\hline$R^{2}$ & 0.699 & 0.693 & 0.690 & 0.652 & 0.999 & 0.991 \\
\hline$\chi^{2}$ & 3.311 & 2.557 & 6.078 & 9.122 & 0.141 & 0.044 \\
\hline \multicolumn{7}{|c|}{ Freundlich } \\
\hline $\begin{array}{l}K_{\mathrm{F}}(\mathrm{mg} / \mathrm{g}) \times \\
\times(\mathrm{l} / \mathrm{g})^{1 / n}\end{array}$ & 1.499 & 3.418 & 1.627 & 2.033 & 1.178 & 0.728 \\
\hline $1 / n$ & 0.445 & 0.332 & 0.388 & 0.103 & 0.539 & 0.581 \\
\hline$R^{2}$ & 0.926 & 0.987 & 0.978 & 0.644 & 0.803 & 0.607 \\
\hline$\chi^{2}$ & 2.354 & 2.023 & 1.031 & 8.016 & 5.669 & 5.527 \\
\hline \multicolumn{7}{|c|}{ Temkin } \\
\hline$A_{\mathrm{T}}, 1 / \mathrm{mg}$ & 3.297 & 4.188 & 4.536 & 1.848 & 8.349 & 8.308 \\
\hline$b_{\mathrm{T}}, \mathrm{J} / \mathrm{mol}$ & 46.47 & 53.18 & 85.99 & 7.586 & 346.9 & 284.7 \\
\hline$R^{2}$ & 0.799 & 0.839 & 0.899 & 0.668 & 0.972 & 0.973 \\
\hline$\chi^{2}$ & 1.118 & 1.222 & 1.217 & 0.442 & 0.785 & 0.846 \\
\hline \multicolumn{7}{|c|}{ Dubinin-Radushkevich } \\
\hline$q_{\mathrm{s}}, \mathrm{mg} / \mathrm{g}$ & 33.01 & 36.99 & 22.22 & 4.703 & 47.01 & 53.29 \\
\hline$E, \mathrm{~kJ} / \mathrm{mol}$ & 13.87 & 11.32 & 12.13 & 0.826 & 7.031 & 7.333 \\
\hline$R^{2}$ & 1.000 & 0.929 & 0.999 & 0.949 & 0.724 & 0.873 \\
\hline$\chi^{2}$ & 5.397 & 3.269 & 7.344 & 0.746 & 0.077 & 0.177 \\
\hline
\end{tabular}

As can be seen from Table 4, the $q$ values according to the D-R equation is insignificantly higher than those estimated with the use of the Langmuir model. Similar results have been reported by other authors $[10 ; 40]$ and can be attributed to the fact that the $\mathrm{D}-\mathrm{R}$ isotherm considers a pore-filling mechanism. According to [18], values of mean free energy of sorption, $E$, less than $8 \mathrm{~kJ} / \mathrm{mol}$ are associated with physical sorption, whereas values between 8 and $16 \mathrm{~kJ} / \mathrm{mol}$ indicate an ion-exchange mechanism of sorption. Thereby, the uptake of cationic dyes onto LCS is generally caused by weaker physical interactions, such as electro-dipole interactions, whereas the intake of EY, AR, and MO possibly occurring due to ion exchange binding. Presumably, the removal of AY

Table 5. Kinetic Parameters

for the Adsorption of Dyes onto LCS

\begin{tabular}{|c|c|c|c|c|c|c|}
\hline \multirow{2}{*}{ Parameter } & \multicolumn{6}{|c|}{ Dye } \\
\hline & EY & AR & MO & $\mathrm{AY}$ & MB & NR \\
\hline$q_{\mathrm{e}}^{\exp }, \mathrm{mg} / \mathrm{g}$ & \multicolumn{4}{|c|}{ Pseudo-first-order } & 26.52 & |31.4 \\
\hline$k_{1} \times 10^{-5}, 1 / \mathrm{min}$ & 9.000 & 9.000 & 9.000 & 6.000 & 8.000 & 8.000 \\
\hline$q_{\mathrm{e}}, \mathrm{mg} / \mathrm{g}$ & 5.609 & 6.015 & 6.062 & 12.83 & 2.588 & 1.531 \\
\hline$R^{2}$ & 0.667 & 0.771 & 0.851 & 0.761 & 0.566 & 0.491 \\
\hline \multirow[t]{2}{*}{$\chi^{2}$} & 239.3 & 53.66 & 5.484 & 48.58 & 61.32 & 229. \\
\hline & \multicolumn{5}{|c|}{ Pseudo-second-order } & \\
\hline$k_{2}, \mathrm{~g} /(\mathrm{mg} \cdot \min )$ & $0.051 \mid$ & 0.031 & 0.044 & 0.042 & 0.037 & 0.105 \\
\hline$q_{\mathrm{e}}, \mathrm{mg} / \mathrm{g}$ & 19.61 & 23.50 & 22.89 & 8.193 & 28.19 & 31.4 \\
\hline$R^{2}$ & 1.000 & 0.999 & 0.999 & 0.699 & 1.000 & 0.995 \\
\hline \multirow[t]{2}{*}{$\chi^{2}$} & 0.018 & 0.063 & 6.488 & 107.0 & 1.605 & 3.98 \\
\hline & \multicolumn{6}{|c|}{ Dubinin-Radushkevich } \\
\hline$k_{3}, \mathrm{mg} /\left(\mathrm{g} \cdot \min ^{0.5}\right)$ & $|0.055|$ & 0.018 & 0.061 & 0.052 & 0.032 & 0.104 \\
\hline$C^{*}, \mathrm{mg} / \mathrm{g}$ & 16.74 & 17.96 & 17.56 & 4.016 & 23.55 & 21.33 \\
\hline$R^{2}$ & 0.683 & 0.417 & 0.782 & 0.978 & 0.525 & 0.697 \\
\hline \multirow[t]{2}{*}{$\chi^{2}$} & 23.34 & 3.230 & 4.852 & 0.654 & 2.938 & 65.98 \\
\hline & \multicolumn{4}{|c|}{ Elovich } & & \\
\hline$\alpha, \mathrm{mg} /(\mathrm{g} \cdot \min )$ & 9.095 & 10.31 & 10.56 & 0.851 & 18.09 & |14.61 \\
\hline$\beta, \mathrm{g} / \mathrm{mg}$ & 0.128 & 0.091 & 0.081 & 0.263 & 0.043 & 0.033 \\
\hline$R^{2}$ & 0.838 & 0.936 & 0.981 & 0.577 & 0.744 & 0.612 \\
\hline \multirow[t]{2}{*}{$\chi^{2}$} & 0.986 & 0.187 & 0.121 & 1.889 & 1.441 & 2.830 \\
\hline & \multicolumn{5}{|c|}{ Boyd film diffusion } & \\
\hline Intercept & 0.583 & 0.895 & 0.950 & 0.206 & 1.865 & 2.086 \\
\hline$R^{2}$ & 0.667 & 0.851 & 0.771 & 0.761 & 0.567 & 0.492 \\
\hline
\end{tabular}


was caused by weak hydrogen bonds. The low values of the $R^{2}$ indicate the unsuitability of the $\mathrm{D}-\mathrm{R}$ isotherm model for cationic dyes, proving that uptake of these dyes does not occur within the pores of LCS.

Adsorption kinetics. The effect of contact time on LCS dye removal is presented in Fig. 3.

Balance achievement increases rapidly with contact time in the first 30 minutes, after which the rate of sorption decreases. For practical purposes, the equilibrium is considered to have been reached within 1 hour. The kinetic data summarized in Table 5.

Correlation coefficients of the pseudo-first-order model are lower than those of the pseudo-second model. Furthermore, the $\chi^{2}$ values are higher in the case of pseudo-first-order kinetics compared to those obtained for pseudo-second-order. Furthermore, the $q_{\mathrm{e}}$ values calculated by equation (8) do not correspond to experimental values $\left(q_{\mathrm{e}}^{\exp }\right)$. Ipso facto, the pseudo-first-order kinetic model does not adequately describe the adsorption of dyes onto LCS. High values of $R^{2}$ and good correspondence between calculated and experimental values in the case of cationic and anionic dyes confirm that the speed of the sorption process is correctly described by pseudo-secondorder equation (9). Similar results have recently been shown in $[1 ; 23]$.

The maximum value of $R^{2}$ and the lowest $\chi^{2}$ for AY suggest that adsorption of nonionic dye in LCS is a diffusion mass transfer process. Therefore, unlike cationic and anionic dyes, AY adsorption occurs within pores of the LCS particles and is limited by diffusion.

On the other hand, high correlation coefficients of the Elovich equation in the case of anionic dyes revealed that their adsorption in LCS was an ion exchange reaction [27]. Therefore, adsorption of MO, AR, and EY in LCS can occur through interaction between functional groups of sorbent and dye, for example:

$$
\begin{aligned}
& \text { LCS-OPO }(\mathrm{OH})-\mathrm{O}^{-} \mathrm{H}^{+}+\mathrm{Na}^{+}\left[\mathrm{dye}^{-}\right] \leftrightarrow \\
& \leftrightarrow \mathrm{LCS}-\mathrm{OPO}(\mathrm{OH})-\mathrm{ONa}[\mathrm{dye}]+\mathrm{H}^{+} .
\end{aligned}
$$

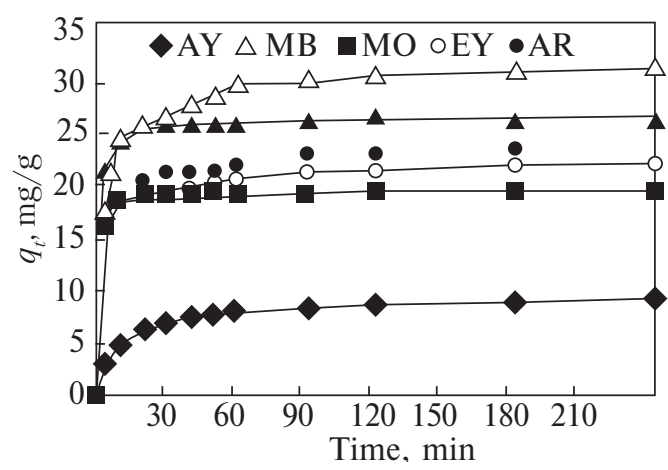

Fig. 3. Effect of contact time on the adsorption capacity of dyes onto LCS. Operating conditions: $C_{0}=1 \cdot 10^{-3} \mathrm{~mol} / \mathrm{l}$; LCS dosage $1 \mathrm{~g} / \mathrm{l} ; \mathrm{pH}=7.0$; temperature $298 \mathrm{~K}$

According to the experimental data in Table 5, the intersections of all dyes were not zero (linear plots did not pass through the origins), indicating external diffusion as a speed-controlling step in the early stages of sorption [41]. Therefore, we suggest that the adsorption rate could be controlled by diffusion of the film (except AY). Adsorption of cationic and anionic dyes in LCS is limited by external diffusion, while intraparticle diffusion is also involved, but is not the rate-limiting step. Similar results have been previously reported in $[11 ; 42]$.

Thermodynamics studies. The thermodynamic parameters $\Delta H^{0}$ and $\Delta S^{0}$ were estimated by plotting $\ln q_{\mathrm{e}} / C_{\mathrm{e}}$ versus $1 / T$ and summarized in Table 6 .

At all temperatures, $\Delta G^{0}$ values are negative and decrease with increasing temperature, indicating that the adsorption of cationic dyes in LCS is spontaneous and thermodynamically feasible [43]. As demonstrated in [18], $\Delta G^{0}$ values down to $-20 \mathrm{~kJ} / \mathrm{mol}$ correspond to physical sorption (van der Waals forces, hydrogen bonds, electrostatic interactions), while $\Delta G^{0}$ values are more negatives than $40 \mathrm{~kJ} / \mathrm{mol}$ indicates the formation of coordinated bonds (chemical sorption). As shown in Table 4, the general dispersion of $\Delta G^{0}$ values suggests that physical sorption is the predominant adsorption mechanism for each class of dyes. Similar results have been reported in previous studies on WS-based sorbents [9; $21 ; 22 ; 27 ; 41]$.

Positive values of $\Delta H^{0}$ indicate the endothermic nature of adsorption, which is in good agree- 
ment with a decrease in $\Delta G^{0}$ with increasing temperature. Relatively low values ( 1.1 to $3.3 \mathrm{~kJ} / \mathrm{mol}$ ) corroborate that the sorption process occurs by a combination of physical hydrogen bonds and van der Waals forces (in the case of anionic and nonionic dyes) and electrostatic attractions (in case of cationic dyes).

A direct correlation was found between the $\Delta H^{0}$ values and the molar mass of the dyes. Experimental data reveals an increasing trend of $\Delta H^{0}$ in the following sequence $\mathrm{EY}>\mathrm{MO}>\mathrm{AR}>-$ $>\mathrm{MB}>\mathrm{NR}>\mathrm{AY}$.

The positive value of $\Delta S^{0}$ for each dye characterizes an increase in randomness at the solidliquid interface during sorption [32]. The increase in the degree of freedom of the adsorbed dye consecutively reduces $\mathrm{EY}>\mathrm{AY}>\mathrm{AR}>\mathrm{NR}>$ $>\mathrm{MO}>\mathrm{MB}$, which could be caused by the degree of complexity of the dye molecule (see Table 1). Therefore, the presence of such functional groups, such as $-\mathrm{NO}_{2}$ or $-\mathrm{NH}_{2}$, considerably enhances the interaction of the dye with the LCS surface.

Table 6. Thermodynamic Parameters

for the Adsorption of Dyes onto LCS

\begin{tabular}{|l|c|c|c|c|c|c|c|}
\hline Dye & $\begin{array}{c}\text { Tempe- } \\
\text { rature, } \\
\mathrm{K}\end{array}$ & $\begin{array}{c}\Delta H_{\mathrm{x}^{\prime}} \\
\mathrm{kJ} / \mathrm{mol}\end{array}$ & $\begin{array}{c}\Delta G^{0}, \\
\mathrm{~kJ} / \mathrm{mol}\end{array}$ & $\begin{array}{c}\Delta H^{0}, \\
\mathrm{~kJ} / \mathrm{mol}\end{array}$ & $\begin{array}{c}\Delta S^{0}, \mathrm{~J} / \\
(\mathrm{mol} \cdot \mathrm{K})\end{array}$ & $R^{2}$ & $\chi^{2}$ \\
\hline EY & 278 & 2.02 & -21.62 & 3.26 & 81.11 & 0.988 & 1.254 \\
& 298 & 2.17 & -20.91 & & & & \\
& 323 & 2.35 & -20.73 & & & & \\
$\mathrm{AR}$ & 278 & 3.18 & -17.68 & 2.79 & 67.97 & 0.991 & 1.265 \\
& 298 & 3.41 & -17.47 & & & & \\
& 323 & 3.69 & -16.79 & & & & \\
MO & 278 & 2.80 & -17.61 & 3.12 & 19.57 & 0.996 & 1.235 \\
& 298 & 3.01 & -17.21 & & & & \\
& 323 & 3.26 & -16.97 & & & & \\
$\mathrm{AY}$ & 278 & 1.98 & -21.22 & 1.07 & 74.19 & 0.781 & 3.232 \\
& 298 & 2.12 & -18.04 & & & & \\
& 323 & 2.30 & -19.18 & & & & \\
MB & 278 & 4.54 & -2.98 & 2.77 & 13.36 & 0.997 & 0.995 \\
& 298 & 4.87 & -1.21 & & & & \\
& 323 & 5.27 & -0.26 & & & & \\
NR & 278 & 3.47 & -4.43 & 2.59 & 67.80 & 0.997 & 0.996 \\
& 298 & 3.72 & -2.71 & & & & \\
& 323 & 4.03 & -0.95 & & & & \\
\hline
\end{tabular}

Positive $\Delta H_{\mathrm{x}}$ values (see Table 6 ) confirm the endothermic nature of sorption and correspond to physical adsorption. As a result, isosteric sorption heat of all dyes increases with growing temperature. The following tendency of $\Delta H_{\mathrm{x}}$ values was observed: $\mathrm{MB}>\mathrm{NR}>\mathrm{AR}>\mathrm{MO}>\mathrm{EY}>\mathrm{AY}$. The highest $\Delta H_{\mathrm{x}}$ values were obtained for the adsorption of cationic dyes due to the interaction of phosphorous ether groups on the surface of LCS with MB and NR. Respectively, there was less intense interaction between LCS and the negatively or neutrally charged dye molecules.

Upon the appearance of hydrophobic groups in dye molecules (for example, AR, MO) and LCS, a noticeable change in positive entropy occurs, which indicates the release of water molecules during the interaction between the dye and sorbent during the association at the phase boundary. The high degree of hydrophobization of LCS, achieved by phosphorylation of its cellulose base, enhances the positive entropy effect and leads to endothermic adsorption effect.

At the same time, all these effects are weakened when the dyestuff molecules charge changes, and $\mathrm{N}=\mathrm{N}$ bonds appear in it due to the predominance of hydrogen bonds in the adsorption mechanism of monoazo dyes onto LCS. The increase in the number of condensed aromatic rings in the molecules of anthraquinone and xanthene dyes leads to the same result.

The ratio of enthalpy and entropy change in the processes of dyes adsorption onto LCS follows a general pattern. It was found that thermodynamic characteristics of dyestuff adsorption and an increase in the molecular weight of synthetic dyes are interrelated.

Table 7 provides a comparison of the performance of different types of WS and AS-based lignocellulosic sorbents for cationic and anionic dyes removal from water.

The results of the present study indicate that LCS has an adsorption capacity comparable to previously developed green sorbents. Production of LCS allows utilizing the large-tonnage waste, being, thus, of current interest for Ukraine. Ad- 
ditionally, the production of LCS enables the use of secondary effluents as liquid fertilizer.

A sustainable method developed for the treatment of lignocellulosic waste, involving delignification and phosphorylation, provides LSC with phosphorus-ether surface groups. Preliminary characterization of LCS as a sorbent has been completed and MB, NR, MO, AR, EY, and AY dyes have been successfully removed from aqueous solutions in batch mode. The elimination of cationic and anionic dyes by LCS is a thermodynamically feasible, spontaneous, and endothermic process, which corresponds to the pseudo-second-order kinetic equation of rate and occurs mainly due to physical sorption. The adsorption of cationic dyes occurs via electrostatic interactions, while anio- nic and non-ionic dyes are adsorbed on the LCS by hydrogen bonding and Van der Waals forces. At an initial concentration of $1 \mathrm{mmol} / \mathrm{L}$, the maximum adsorption capacities for MB, NR, MO, $\mathrm{AR}, \mathrm{EY}$, and $\mathrm{AY}$ were determined as, $\mathrm{mg} / \mathrm{g}: 26.5$; $31.5 ; 22.3 ; 23.6 ; 19.6$, and 4.08 , respectively. FTIR study has demonstrated the presence of phosphorous ether functional groups on the surface of LCS, which are responsible for dye's adsorption.

Current work has indicated that LCS can be successfully utilized as a green sorbent for the cationic, and anionic dyes removal from water. Experimental results have characterized LCS as an effective sorbent for the water treatment and encourage further studies on the applicability of LCS for removal of metal ions from industrial effluents.

Table 7. Adsorption Capacities of Sorbents Derived from WS and AS towards Various Dyes

\begin{tabular}{|c|c|c|c|c|c|}
\hline \multicolumn{2}{|r|}{ Dye } & \multicolumn{2}{|r|}{ Sorbent } & \multirow{2}{*}{$q_{\mathrm{m}}, \mathrm{mg} / \mathrm{g}$} & \multirow{2}{*}{ Reference } \\
\hline Commercial name & Class (series) & Basis & Modifying agent & & \\
\hline $\begin{array}{l}\text { Reactive brilliant red } \\
\text { K-2BP }\end{array}$ & Anionic acid (monoazo) & WS & $\begin{array}{l}\text { Epichlorohydrin; } \\
\text { diethylenetriamine }\end{array}$ & 568.18 & {$[27]$} \\
\hline Reactive brilliant blue & Anionic acid (anthraquinone) & WS & $\begin{array}{l}\text { Epichlorohydrin; } \\
\text { aspartic acid }\end{array}$ & 224.42 & [9] \\
\hline Acid green 25 & Anionic acid (anthraquinone) & WS & - & 21.0 & {$[43]$} \\
\hline Acid red 183 & Anionic acid (monoazo) & WS & - & 45.0 & {$[43]$} \\
\hline Acid red 97 & Anionic acid (disazo) & WS & - & 29.15 & {$[40]$} \\
\hline Violet B & Anionic acid (disazo) & WS & - & 48.7 & {$[16]$} \\
\hline Murexide & Anionic acid (azomethine) & WS & $\mathrm{CH}_{3} \mathrm{COOH}$ & 12.0 & {$[1]$} \\
\hline Congo red & Anionic amphoteric (disazo) & WS & $\mathrm{H}_{3} \mathrm{PO}_{4}$ & 40.0 & {$[10]$} \\
\hline Rhodamine B & Cationic amphoteric (xanthene) & WS & - & 2.29 & {$[7]$} \\
\hline Maxilon red GRL & Cationic basic (monoazo) & WS & - & 58.21 & [42] \\
\hline Malachite green & Cationic basic (triphenylmethane) & WS & - & 90.8 & {$[41]$} \\
\hline Methyl violet & Cationic basic (triphenylmethane) & WS & $\mathrm{CH}_{3} \mathrm{COOH}$ & 55.0 & {$[1]$} \\
\hline Methylene blue & Cationic basic (thiazine) & WS & - & 51.55 & {$[21]$} \\
\hline Methylene blue & Cationic basic (thiazine) & WS & - & 178.9 & {$[22]$} \\
\hline Methylene blue & Cationic basic (thiazine) & WS & $\mathrm{CH}_{3} \mathrm{COOH}$ & 60.0 & [1] \\
\hline Methylene blue & Cationic basic (thiazine) & WS & $\mathrm{NaOH}$ & 95.24 & [11] \\
\hline Methylene blue & Cationic basic (thiazine) & WS & $\mathrm{KOH}$ & 33.67 & [23] \\
\hline Methylene blue & Cationic basic (thiazine) & WS & $\mathrm{H}_{3} \mathrm{PO}_{4} ; \mathrm{CO}\left(\mathrm{NH}_{2}\right)^{2}$ & 47.01 & Present study \\
\hline Neutral red & Cationic basic (azine) & WS & $\mathrm{H}_{3} \mathrm{PO}_{4} ; \mathrm{CO}\left(\mathrm{NH}_{2}\right)^{2}$ & 53.29 & Present study \\
\hline Methyl orange & Anionic acid (monoazo) & WS & $\mathrm{H}_{3} \mathrm{PO}_{4} ; \mathrm{CO}\left(\mathrm{NH}_{2}\right)^{2}$ & 22.22 & Present study \\
\hline Eosin $\mathrm{Y}$ & Anionic acid (xanthene) & WS & $\mathrm{H}_{3} \mathrm{PO}_{4} ; \mathrm{CO}\left(\mathrm{NH}_{2}\right)^{2}$ & 33.01 & Present study \\
\hline Alizarin red S & Anionic acid (anthraquinone) & WS & $\mathrm{H}_{3} \mathrm{PO}_{4} ; \mathrm{CO}\left(\mathrm{NH}_{2}\right)^{2}$ & 36.99 & Present study \\
\hline Aniline yellow & Non-ionic basic (monoazo) & WS & $\mathrm{H}_{3} \mathrm{PO}_{4} ; \mathrm{CO}\left(\mathrm{NH}_{2}\right)^{2}$ & 4.70 & Present study \\
\hline
\end{tabular}




\section{REFERENCES}

1. Halysh, V., Sevastyanova, O., Riazanova, A. V., Pasalskiy, B., Budnyak, T., Lindström, M. E., Kartel, M. (2018). Walnut shells as a potential low-cost lignocellulosic sorbent for dyes and metal ions. Cellulose, 25, 4729-4742. https://doi. org/10.1007/s10570-018-1896-y

2. Queirós, C. S. G. P., Cardoso, S., Lourenço, A., Ferreira, J., Miranda, I., Lourenço, M. J. V., Pereira, H. (2019). Characterization of walnut, almond, and pine nut shells regarding chemical composition and extract composition. Biomass Conversion and Biorefinery, 10, 175-188. https://doi.org/10.1007/s13399-019-00424-2

3. Angin, D. (2014). Utilization of activated carbon produced from fruit juice industry solid waste for the adsorption of Yellow 18 from aqueous solutions. Bioresource Technology, 168, 259-266. https://doi.org/10.1016/j.biortech.2014.02.100

4. Jahanban-Esfahlan, A., Ostadrahimi, A., Tabibiazar, M., Amarowicz, R. (2019). A comprehensive review on the chemical constituents and functional uses of walnut (Juglans spp.) husk. International Journal of Molecular Sciences, $20,3920$. https://doi.org/10.3390/ijms20163920

5. Bordbar, M., Mortazavimanesh, N. (2016). Green synthesis of Pd/walnut shell nanocomposite using Equisetum arvense L. leaf extract and its application for the reduction of 4-nitrophenol and organic dyes in a very short time. Environmental Science and Pollution Research, 24, 4093-4104. https://doi.org/10.1007/s11356-016-8183-y

6. Gupta, V. K., Suhas. (2009). Application of low-cost adsorbents for dye removal - A review. Journal of Environmental Management, 90(8), 2313-2342. https://doi.org/10.1016/j.jenvman.2008.11.017

7. Shah, J., Rasul Jan, M., Haq, A., Khan, Y. (2013). Removal of Rhodamine B from aqueous solutions and wastewater by walnut shells: kinetics, equilibrium and thermodynamics studies. Frontiers of Chemical Science and Engineering, 7, 428436. https://doi.org/10.1007/s11705-013-1358-x

8. Hokkanen, S., Bhatnagar, A., Sillanpää, M. (2016). A review on modification methods to cellulose-based adsorbents to improve adsorption capacity. Water Research, 91, 156-173. https://doi.org/10.1016/j.watres.2016.01.008

9. Li, S., Zeng, Z., Xue, W. (2019). Kinetic and equilibrium study of the removal of reactive dye using modified walnut shell. Water Science E Technology, 80, 874-883. https://doi.org/10.2166/wst.2019.324

10. Ojo, T. A., Ojedokun, A. T., Bello, O. S. (2017). Functionalization of powdered walnut shell with phosphoric acid for Congo red dye removal. Particulate Science and Technology, 11, 74-85. https://doi.org/10.1080/02726351.2017.1340914

11. Namal, O. O., Kalipci, E. (2018). Adsorption kinetics of methylene blue using alkali and microwave-modified apricot stones. Separation Science and Technology, 54, 1722-1738. https://doi.org/10.1080/01496395.2018.1541469

12. Abdolali, A., Guo, W. S., Ngo, H. H., Chen, S. S., Nguyen, N. C., Tung, K. L. (2014). Typical lignocellulosic wastes and by-products for biosorption process in water and wastewater treatment: A critical review. Bioresource Technology, 160, 57-66. https://doi.org/10.1016/j.biortech.2013.12.037

13. Jahanban-Esfahlan, A., Jahanban-Esfahlan, R., Tabibiazar, M., Roufegarinejad, L., Amarowicz, R. (2020). Recent advances in the use of walnut (Juglans regia L.) shell as a valuable plant-based bio-sorbent for the removal of hazardous materials. RSC Advances, 10, 7026-7047. https://doi.org/10.1039/c9ra10084a

14. Ben Arfi, R., Karoui, S., Mougin, K. Ghorbal, A. (2017). Adsorptive removal of cationic and anionic dyes from aqueous solution by utilizing almond shell as bioadsorbent. Euro-Mediterranean Journal for Environmental Integration, 2 , 20. https://doi.org/10.1007/s41207-017-0032-y

15. Değermenci, G. D., Değermenci, N., Ayvaoğlu, V., Durmaz, E., Çakır, D., Akan, E. (2019). Adsorption of reactive dyes on lignocellulosic waste; Characterization, Equilibrium, Kinetic and Thermodynamic Studies. Journal of Cleaner Production, 225, 1220-1229. https://doi.org/10.1016/j.jclepro.2019.03.260

16. Hashemian, S., Shayegan, J. (2014). A comparative study of cellulose agricultural wastes (almond shell, pistachio shell, walnut shell, tea waste and orange peel) for adsorption of violet b dye from aqueous solutions. Oriental Journal of Chemistry, 30, 2091-2098. https://doi.org/10.13005/ojc/300478

17. Soldatkina, L., Zavrichko, M. (2018). Equilibrium, kinetic, and thermodynamic studies of anionic dyes adsorption on corn stalks modified by cetylpyridinium bromide. Colloids Interfaces, 3, 4. https://doi.org/10.3390/colloids3010004

18. Suteu, D., Zaharia, C., Malutan, T. (2012). Equilibrium, kinetic, and thermodynamic studies of Basic Blue 9 dye sorption on agro-industrial lignocellulosic materials. Central European Journal of Chemistry, 10, 1913-1926. https://doi.org/ $10.2478 / \mathrm{s} 11532-012-0122-2$

19. Ben'ko, E. M., Lunin, V. V. (2018). Adsorption of methylene blue on lignocellulosic plant materials. Russian Journal of Physical Chemistry A, 92, 1794-1798. https://doi.org/10.1134/S0036024418090066

20. Yagub, M. T., Sen, T. K., Afroze, S., Ang, H. M. (2014). Dye and its removal from aqueous solution by adsorption: A review. Advances in Colloid and Interface Science, 209, 172-184. https://doi.org/10.1016/j.cis.2014.04.002

21. Tang, R., Dai, C., Li, C., Liu, W., Gao, S., Wang, C. (2017). Removal of methylene blue from aqueous solution using agricultural residue walnut shell: equilibrium, kinetic, and thermodynamic studies. Journal of Chemistry, 1-10. https://doi. org/10.1155/2017/8404965 
22. Miyah, Y., Lahrichi, A., Idrissi, M., Khalil, A., Zerrouq, F. (2018). Adsorption of methylene blue dye from aqueous solutions onto walnut shells powder: equilibrium and kinetic studies. Surfaces and Interfaces, 11, 74-81. https://doi. org/10.1016/j.surfin.2018.03.006

23. Namal, O. O., Kalipci, E. (2019). Adsorption kinetics of methylene blue removal from aqueous solutions using potassium hydroxide $(\mathrm{KOH})$ modified apricot kernel shells. International Journal of Environmental Analytical Chemistry, 1-17. https://doi.org/10.1080/03067319.2019.1656721

24. Salleh, M. A. M., Mahmoud, D. K., Abdul Karim, W. A. W., Idris, A. (2011). Cationic and anionic dye adsorption by agricultural solid wastes: A comprehensive review. Desalination, 280(1-3), 1-13. https://doi.org/10.1016/j.desal.2011.07.019

25. Rangabhashiyam, S., Anu, N., Selvaraju, N. (2013). Sequestration of dye from textile industry wastewater using agricultural waste products as adsorbents. Journal of Environmental Chemical Engineering, 1(4), 629-641. https://doi.org/ 10.1016/j.jece.2013.07.014

26. Adegoke, K. A., Bello, O. S. (2015). Dye sequestration using agricultural wastes as adsorbents. Water Resources and Industry, 12, 8-24. https://doi.org/10.1016/j.wri.2015.09.002

27. Cao, J.-S., Lin, J.-X., Fang, F., Zhang, M. T., Hu, Z. R. (2014). A new absorbent by modifying walnut shell for the removal of anionic dye: Kinetic and thermodynamic studies. Bioresource Technology, 163, 199-205. https://doi.org/10.1016/j. biortech.2014.04.046

28. Gurr, E. (1971). Synthetic dyes in biology, medicine and chemistry. London, UK: Academic Press. https://doi.org/10.1016/ B978-0-123-09650-0.X5001-7

29. Chen, W., Yu, H., Liu, Y. (2011). Preparation of millimeter-long cellulose I nanofibers with diameters of 30-80 nm from bamboo fibers. Carbohydrate Polymers, 86(2), 453-461. https://doi.org/10.1016/j.carbpol.2011.04.061

30. Zheng, D., Zhang, Y., Guo, Y., Yue, J. (2019). Isolation and characterization of nanocellulose with a novel shape from walnut (Juglans Regia L.) shell agricultural waste. Polymers, 11, 1130. https://doi.org/10.3390/polym11071130

31. Demirbas, E., Kobya, M., Sulak, M. T. (2008). Adsorption kinetics of a basic dye from aqueous solutions onto apricot stone activated carbon. Bioresource Technology, 99(13), 5368-5373. https://doi.org/10.1016/j.biortech.2007.11.019

32. Foo, K. Y., Hameed, B. H. (2010). Insights into the modeling of adsorption isotherm systems. Chemical Engineering Journal, 156(1), 2-10. https://doi.org/10.1016/j.cej.2009.09.013

33. Saadi, R., Saadi, Z., Fazaeli, R., Fard, N. E. (2015). Monolayer and multilayer adsorption isotherm models for sorption from aqueous media. Korean Journal of Chemical Engineering, 32, 787-799. https://doi.org/10.1007/s11814-015-0053-7

34. Qiu, H., Lv, L., Pan, B. C., Zhang, Q., Zhang, W., Zhang, Q. (2009). Critical review in adsorption kinetic models. Journal of Zhejiang University, 10, 716-724. https://doi.org/10.1631/jzus.A0820524

35. Al-Ghouti, M., Da'ana, D. (2020). Guidelines for the use and interpretation of adsorption isotherm models: A review. Journal of Hazardous Materials, 393, 122383. https://doi.org/10.1016/j.jhazmat.2020.122383

36. Corbett, D., Kohan, N., Machado, G., Jing, C., Nagardeolekar, A., Bujanovic, B. (2015). Chemical composition of apricot pit shells and effect of hot-water extraction. Energies, 8, 9640-9654. https://doi.org/10.3390/en8099640

37. Ilczyszyn, M. M., Ratajczak, H., Barnes, A. J. (1992). Polarized infrared and Raman spectra of urea-phosphoric acid and urea-arsenic acid single crystals. Journal of Raman Spectroscopy, 23, 1-13. https://doi.org/10.1002/jrs.1250230102

38. Illy, N., Fache, M., Ménard, R., Negrell, C., Caillol S., David, G. (2015). Phosphorylation of bio-based compounds: the state of the art. Polymer Chemistry, 6, 6257-6291. https://doi.org/10.1039/c5py00812c

39. Ahn, B., Choi, U., Kwon, O. (2000). Electro-rheological properties of anhydrous ER suspensions based on phosphoric ester cellulose particles. Polymer International, 49, 567-573. https://doi.org/10.1002/1097-0126(200006)49:6<567::aidpi416>3.0.co;2-t

40. Ghazi Mokri, H. S., Modirshahla, N., Behnajady, M. A., Vahid, B. (2015). Adsorption of C.I. Acid Red 97 dye from aqueous solution onto walnut shell: kinetics, thermodynamics parameters, isotherms. International Journal of Environmental Science and Technology, 12, 1401-1408. https://doi.org/10.1007/s13762-014-0725-6

41. Dahri, M. K., Kooh, M. R. R., Lim, L. B. L. (2014). Water remediation using low cost adsorbent walnut shell for removal of malachite green: Equilibrium, kinetics, thermodynamic and regeneration studies. Journal of Environmental Chemical Engineering, 2(3), 1434-1444. https://doi.org/10.1016/j.jece.2014.07.008

42. Deniz, F. (2014). Effective removal of Maxilon Red GRL from aqueous solutions by walnut shell: Nonlinear kinetic and equilibrium models. Environmental Progress E Sustainable Energy, 33, 396-401. https://doi.org/10.1002/ep.11797

43. Aydin, H., Baysal, G., Bulut, Y. (2009). Utilization of walnut shells (Juglans regia) as an adsorbent for the removal of acid dyes. Desalination and Water Treatment. 2, 141-150. https://doi.org/10.5004/dwt.2009.251

Received 26.10.2020

Revised 15.02.2021 Accepted 29.03.2021 
Д.О. Слатонцев ${ }^{1,2}$ (https://orcid.org/0000-0003-1043-418X),

А.П. Мухачев ${ }^{2}$ (https://orcid.org/0000-0002-6025-3988),

O.B. Іванюк ${ }^{3}$ (https://orcid.org/0000-0003-4112-837X)

${ }^{1}$ Дніпровський державний технічний університет, вул. Дніпробудівська, 2, Кам'янське, 51918, Дніпропетровська область, Україна, +380569560667, science@dstu.dp.ua

${ }^{2}$ Інститут геотехнічної механіки ім. Н. Полякова НАН України, вул. Сімферопольська, 2, Дніпро, 49005, Україна, +380 567460151 , igtmnanu@ukr.net

${ }^{3}$ Національний технічний університет України «Київський політехнічний інститут імені Ігоря Сікорського», просп. Перемоги, 37, Київ, 03056, Україна,

+380442048573, sec@xtf.kpi.ua

\section{ЕФЕКТИВНИЙ БІОСОРБЕНТ ДЛЯ ОЧИЩЕННЯ ВОДИ, ОТРИМАНИЙ З ВИРОБНО-ТЕХНОЛОГІЧНИХ ВІДХОДІВ: ДОСЛІДЖЕННЯ АДСОРБЦІЇ СИНТЕТИЧНИХ ФАРБНИКІВ}

Вступ. Ефективна утилізація харчових відходів, зокрема горіхової шкаралупи та плодових кісточок, є важливим питанням забезпечення сталого природокористування. Ця вторинна сировина є джерелом цінних полімерних матеріалів - целюлози та лігніну.

Проблематика. Враховуючи потужності харчової промисловості України та кількість накопичених відходів, розвиток технологій переробки біомаси є важливою науково-практичною проблемою.

Мета. Дослідження адсорбційних властивостей хімічно-модифікованого біосорбенту на основі рослинної сировини щодо різних класів синтетичних барвників. Оцінка доцільності виробництва біосорбенту та ефективності його застосування у очистці води.

Матеріали та методи. Лігноцелюлозний сорбент (ЛЦС) було синтезовано з недеревної сировини шляхом хімічної модифікації з використанням фосфорної кислоти з додаванням сечовини у водному середовищі. Інфрачервона спектроскопія Фур'є та стандартні методи аналізу рослинної сировини використано для визначення фізико-хімічних характеристик ЛЦС. Досліджено адсорбцію аніонних (метилоранж, алізариновий червоний S, еозин Y), катіонних (метиленовий синій, нейтральний червоний) та неіоногенних (аніліновий жовтий) барвників на ЛЦС з водного розчину.

Результати. Адсорбційна ємність ЛЦС щодо катіонних барвників (47,0-53,3 мг/г) вища, ніж для аніонних (22,236,9 мг/г) та неіоногенних (4,7 мг/г). Кінетика адсорбції адекватно описується рівнянням псевдодругого порядку. Адсорбція всіх класів барвників є термодинамічно можливим, спонтанним ендотермічним процесом. Рідкий побічний продукт виробництва містить 15\% Нітрогену і 10\% Фосфору, тому його можна використовувати як комплексне мінеральне добриво.

Висновки. Запропонований спосіб переробки харчових відходів передбачає отримання ефективного сорбенту та рідкого NP-добрива. Біосорбент видаляє з води катіонні та аніонні полютанти, тому його можна розглядати як перспективний біосорбент для очистки води.

Ключові слова: целюлоза, синтетичні барвники, адсорбція, кінетика, термодинаміка, шкаралупа волоського горіха, абрикосові кісточки, переробка відходів. 